Review article

\title{
Prevalence of musculoskeletal lower back pain among nurses
}

\author{
Andrea Gilchrist ${ }^{1,2 *}$, Andrea Pokorná ${ }^{3}$ \\ ${ }^{1}$ Oxford University Hospitals NHS Foundation Trust, Oxford, United Kingdom \\ ${ }^{2}$ University of Ostrava, Faculty of Medicine, Department of Nursing and Midwifery, Ostrava, Czech Republic \\ ${ }^{3}$ Masaryk University, Faculty of Medicine, Department of Nursing and Midwifery, Brno, Czech Republic
}

\begin{abstract}
Objectives: The aim of this study is to evaluate the scientific findings available on the prevalence of musculoskeletal lower back pain among nursing professionals in an inpatient direct care setting. This literature review is baseline research for further analysis on cross-cultural comparisons of the prevalence of lower back pain among nursing professionals in the Czech Republic and the United Kingdom.

Methods: Rapid literature review - selected keywords according to PICO, using Boolean Allies, were searched in scientific electronic databases (MEDLINE, SCOPUS, EMBASE, CINAHL).

Results: A total of 370 scientific sources were found. After being analysed, 15 sources were subjected to a critical analysis and a total of 8 studies that met the study criteria were selected for the final analysis.

Conclusions: The literature review confirmed that despite 21st century modern technology the prevalence of lower back pain in nursing professionals remains a very serious problem among the examined population of nurses. Studies have shown that the implementation of effective preventive measures of occupational safety is not standardized nor widely implemented in the health care industry around the world. The results of the literature review showed that the nurses' working conditions, lack of awareness of occupational risks, and low emphasis on prevention and safe manual handling education may affect the occurrence of musculoskeletal lower back pain in nurses. Chronic musculoskeletal lower back pain in nursing personnel can lead to frequent absences from work, leaving the profession, and early retirement - which in some regions may worsen the nursing shortage.
\end{abstract}

Keywords: General nurse; Musculoskeletal lower back pain; Prevalence; Prevention; Risk factors

\section{Introduction}

During the course of a hospital stay, patients are frequently assisted by nurses and other members of the healthcare team in performing their basic everyday activities, common movements, changing position and walking. Facilitation of these activities is described in a number of different ways, such as a 'manual handling', 'moving and handling' or 'patient handling' activity. It has been found that helping patients to turn or move in bed, bathe, dress or transfer from chair to toilet places the caregiver at higher risk of soft tissue musculoskeletal disorders and injuries (Kneafsey et al., 2015; Mirmohammadi et al., 2015). Musculoskeletal disorders (MSD) account for almost 20 percent of work disability cases among the general population in the Czech Republic, representing the second most frequent cause of work incapacity after respiratory diseases. Among all musculoskeletal disorders, dorsopathies, particularly of the lumbar part of the back, were the most common (Institute of Health Information and Statistics of the Czech Republic, IHIS CR, 2013). The current data relating to the incidence rate of musculoskeletal disorders among the
Czech population was acquired from IHIS - and since then it has been updated and processed.

Lower back pain (LBP) complaints are the most common reason for the incapacity of nurses to work, causing an increase in the workload of the other nursing staff (Fiter et al., 2018). Studies have also shown that the prevalence of LBP appears to be even higher for nurses and nurses' aides than for women of similar age in the general population (D'Agostin and Negro 2017; Fiter et al., 2018; Hartvigsen et al., 2005). Nurses have been shown to have the highest rates of work-related lower back pain of all health professionals. (Karahan and Bayraktar, 2013).

It is estimated that $12 \%$ of nurses leave the profession annually because of back injuries and that over half of registered nurses complain of chronic back pain (Nelson et al., 2003). These complaints are recognised in the long run as a leading cause for early retirement, which in some regions may worsen the nursing shortage (Simon et al., 2008).

The Czech Occupational Safety Research Institute (2016) emphasizes that reducing the high proportion of work-related illnesses, absenteeism and early retirement in nursing, should be a priority for healthcare organisations worldwide.

\footnotetext{
* Author for correspondence: Andrea Gilchrist, University of Ostrava, Faculty of Medicine, Department of Nursing and Midwifery, Syllabova 19, 70300 Ostrava-Vítkovice, Czech Republic; e-mail: Andrea.Kadlckova@gmail.com http://doi.org/10.32725/kont.2020.020 
Across the European Union, healthcare workers rate their own health and safety at work as poorer than the rest of the working population across Europe (Andersen et al., 2019).

One way of reducing the incidence of staff musculoskeletal injury associated with patient handling has been the implementation of policies and regulations promoting the use of lifts, and the introduction of 'safer patient handling' procedures (Kneafsey et al., 2015).

Manual handling training programs are designed to make workers aware of the risks associated with manual handling as well as providing training in how to reduce the likelihood of becoming injured (Haslam et al., 2007). Furthermore, ergonomics principles of manual handling training aims to promote patients' capacity (not their incapacity) to ensure they are treated with dignity and respect. Maintaining a good level of patient mobility and independence is an essential part of care delivery and can reduce the risk of long-term physical and psychological effects of hospitalization (Warren, 2016).

Although the development of the manual handling training and use of lifting aids are global competencies (Occupational Safety Research Institute, 2016) and are now identified as an important ergonomic control across the westernised world to reduce the risks associated with lifting, moving and pulling loads (Kneafsey el al., 2015), there is still no consistent view of the preferred preventive measures in the Czech Republic (Occupational Safety Research Institute, 2016).

EU occupational safety and health (OSH) directives highlighted the importance of evidence-based policy making to collect reliable, timely and comparable statistical data on work-related accidents and diseases, occupational exposures, work-related ill-health, and to analyse the costs and benefits in the area of OSH (Commission European, 2015).

23 European countries recognize lower back pain disease (LBPD) caused by physical overload as an occupational disease, while Bosnia and Herzegovina, Croatia, Czech Republic, Finland, Great Britain, Ireland, Norway, Poland, Portugal, and Spain do not acknowledge LBPD as an occupational disease caused by an overload of the spine (Laštovková et al., 2015). Due to the fact that some of the member states did not recognize LBPD as an occupational disease it is therefore still difficult to monitor the seriousness of the problem on the nationwide level, or to compare occupational safety and health performance across member states and draw evidence-based policy conclusions from such comparisons (European Commission, 2015).

The European Agency for Safety and Health at Work (EU-OSHA) in line with the EU Strategic Framework on Safety and Health at Work 2014-2020, has declared they will support the prevention of work-related diseases by providing an evidence base for prevention, policy and practice. The aim is to provide a better overview of the extent of the occupational diseases related to the handling of heavy loads and in particular musculoskeletal disorders.

The aim of this literary research is to analyze the published studies related to the incidence rate of musculoskeletal lower back pain in nurses and to identify the incidence rate of the pain in nurses abroad. We have also researched the procedures used by occupational safety management to decrease the occurrence of musculoskeletal lower back pain in nurses worldwide.

The results of this literary research will be used as a basis for a research which will analyze the intercultural differences in the incidence rate of musculoskeletal lower back pain in nurses between the Czech Republic and Great Britain.

\section{Materials and methods}

The fundamental criterion for the selection of studies in this research was that they should be original scientific research studies using varied methods (prospective as well as retrospective studies, quantitative description selective studies, qualitative studies, etc.), and focused on the incidence rate of musculoskeletal lower/lumbar back pain in nurses working in the direct care of patients for providers of inpatient medical care services. All the individual studies analyzed in this research had to meet the requirements for a scientific publication with IMRaD (Introduction, Methods, Results and Discussion). The study includes strictly professional sources studying the incidence rate of musculoskeletal lower/lumbar back pain in nurses working in the direct care of patients.

\begin{tabular}{|c|c|c|}
\hline \multicolumn{2}{|c|}{ PICO } & Inclusion criteria \\
\hline$P$ & $\begin{array}{l}\text { Population / participants } \\
\text { of interest }\end{array}$ & $\begin{array}{l}\text { Registered nurses working in direct } \\
\text { patient care }\end{array}$ \\
\hline I & Intervention & Muskuloskeletal lower back pain \\
\hline C & Comparison & $\begin{array}{l}\text { Prevalence of no musculoskeletal } \\
\text { back pain }\end{array}$ \\
\hline $\mathrm{O}$ & Outcome & $\begin{array}{l}\text { Incidence, prevalence and intensity } \\
\text { of musculoskeletal back pain }\end{array}$ \\
\hline \multicolumn{2}{|c|}{ Study design } & $\begin{array}{l}\text { Descriptive study, Cross-sectional } \\
\text { study }\end{array}$ \\
\hline
\end{tabular}

Studies describing the incidence rate or comparing the occurrence of musculoskeletal lower back pain in other healthcare professions have been omitted in this literary research. The literary overview has been processed in the form of a rapid literature review.

In order to identify only the current information for the previous five (5) years, the search was limited to the period from 2014 to 2019. The language for searching was not initially limited, but the sources that were in any other language than English were subsequently left out. The available sources were searched through the following databases: MEDLINE (OvidSP platform), CINAHL with Full Texts (EBSCOhost platform), SCOPUS and EMBASE (both databases on Elsevier platform). The research only analyzed free articles that are available as full texts.

We analyzed the sources in English that were available through full-text information sources. As far as the searching strategy is concerned, we selected a combination of the following key words: "nurs"” (the star convention was used in order to enlarge the key word by other possible words with the same root, e.g.: nurse, nurses, nursing, etc.). Other key words included "low back pain" and "musculoskeletal back pain", which defined the health difficulties faced by nurses, and these were followed by key words that related to the relevant circumstances, in particular: "prevalence", "incidence", "intensity" (or "pain intensity", if the key word "intensity" was too frequent in the database), pain scale, and a specific scale for pain assessment "Visual analogue scale*" or "Visual analog scale*". The star convention was again used here so as to cover both the singular and the plural of the key word (scale/scales). Initially, we also included the key word "no pain" in the searching strat- 
egy, but the number of records decreased significantly when we used it, and therefore we removed it. The key words were combined by means of the boole operators AND and OR, while the operator NOT was not used, because it is not supported in all the searched databases. The key words were combined as follows: (nurs*) AND (low back pain OR musculoskeletal back pain) AND (intensity OR prevalence OR incidence OR pain scale* OR Visual analogue scale* OR Visual analog scale*). In the databases the key words were most frequently searched in the Title and in the Abstract, and, in accordance with the database options also in other sections (Keyword, Exact Major Subject Heading, etc.).

The search was performed on $24 / 1 / 2020$. The total number of publications identified in the databases was 370. After removing 188 duplicities (by means of EndNote application of the Thomson Reuters Web platform), 182 publications remained available for further analysis.

\section{Description of searching and analyzing strategy}

After reading the titles and résumés, we eliminated the studies that were not in English (Chinese, French, Italian, German, Persian, Polish, Greek), and also studies that were only published as conference abstracts, as well as those that were not relevant to the aim of the research (did not describe nurses, but other healthcare professionals, or nurses working in facilities other than hospitals, etc.). 15 relevant sources were subsequently used for the final assessment and their full texts were found. The procedure of source selection for the literary research is described in Suppl. 1.

The MEDLINE database (OvidSP) included 156 sources in total, of which 54 sources remained after limiting the years to 2014-19. In the second phase, 53 sources were removed based on titles and résumés because of a duplicity of sources and non-compliance with the criteria for inclusion in the analysis, or because of the source being in a language other than English (in this case, Polish and German); $n=1$ source from the database remained for the second phase of the analysis. This was the study by Nourollahi et al. (2018).
154 sources were found in the SCOPUS database (Elsevier) when the period was limited to 2014-2019. Based on the first-stage analysis of the identified studies, 153 sources were removed. The reasons for the removals included duplicities, sources being in a language other than English (Chinese, French, Italian, German and Persian), sources were only published as conference abstracts, or the studies of back pain were completed in other populations. They often provided comparisons with other professions or preferences, and could not thus be used for the purposes of our research. Eventually, we were left with $n=1$ source to use in the second phase of the analysis, in particular the study of Fujii et al. (2019).

The EMBASE database (Elsevier) offered 84 sources that were limited to the period from 2014 to 2019 (as with the SCOPUS database). During the first phase of analyzing the identified studies, 81 sources remained on similar grounds as above, i.e. duplicity of articles, irrelevance to the criteria set by PICO, and abstracts published at conferences. The total of $n=3$ sources remained from this database, in particular studies by: Mekonnen (2019), Sanjoy et al. (2017) and Shieh et al. (2016).

In the CINAHL database (EBSCOhost), we found a total of 173 sources, of which 78 sources were left after limiting to the years 2014-19. 75 sources were removed. The reasons for deletion included: duplicities, conference abstracts, focus on effectiveness of preventive programs, language other than English (Greek), and others failed to meet the required criteria. For the second phase of analysis, we were left with $n=3$ sources, in particular studies by the following authors: Luan et al. (2018), Serranheira et al. (2015), and Suliman (2018).

An overview of suitable studies $(n=15)$ compared to the required criteria of the research is provided in Table 2 below. This table summarizes two main selection criteria, namely whether the study analyzed the incidence of musculoskeletal lower back pain in the nurses' profession only, and whether the nurses worked in institutions providing direct care to patients. All studies that failed to meet both of these criteria for selection have been eliminated.

Table 2. Overview of suitable studies $(n=15)$ compared to the required criteria of the research

\begin{tabular}{lcccc} 
Authors and year of & Study sample & Study design & \multicolumn{2}{c}{ Research criteria } \\
\cline { 2 - 4 } & & & $\begin{array}{c}\text { Study participants are } \\
\text { only registered nurses }\end{array}$ & $\begin{array}{c}\text { Study participants working } \\
\text { in direct patient care }\end{array}$ \\
\hline Mekonnen, 2019 & $N=418$ & Cross-sectional study & Yes & Yes \\
Fujii et al., 2019 & $N=3066$ & Cross-sectional study & Yes & No \\
Gaowgzeh, 2019 & $N=60$ & Cross-sectional study & Yes & Yes \\
Suliman, 2018 & $N=384$ & Cross-sectional study & Yes & Yes \\
Nourollahi et al., 2018 & $N=80$ & Cross-sectional study & Yes & No \\
Abolfotouh et al., 2015 & $N=254$ & Cross-sectional study & Yes & Yes \\
Luan et al., 2018 & $N=1179$ & Cross-sectional study & No & No \\
Dlungwanen et al., 2018 & $N=242$ & Cross-sectional study & No & Yes \\
Skela-Savič et al., 2017 & $N=1744$ & Cross-sectional study & No & Yes \\
Sanjoy et al., 2017 & $N=229$ & Cross-sectional study & Yes \\
Samaei et al., 2017 & $N=243$ & Cross-sectional study & No & Yes \\
Shieh et al., 2016 & $N=788$ & Cross-sectional study & Yes \\
Genç et al., 2016 & $N=416$ & Cross-sectional study & Yes \\
Lee et al., 2015 & $N=396$ & Cross-sectional study & Cross-sectional study & No \\
Serranheira et al., 2015 & $N=1,396$ & & Yes \\
\hline
\end{tabular}


A detailed overview of the topics of individual texts for the two-phase analysis is included in Suppl. 2, which describes the number and characteristics of respondents, the selected type of study and the tools used, as well as the results of incidence and a summary of conclusions and recommendations.

Eight (8) studies that complied with the required criteria of research were presented for the second-phase analysis.

\section{Results and discussion}

The presented literary research provides a detailed analyses of eight professional international sources that comply with the required criteria for a research into incidence rate of musculoskeletal lower back pain in the population of registered nurses working in direct hospital care at the patient's bed.

As has emerged from the analyzed sources, the problem studied is a topical issue frequently analyzed by scientists (in 2019 two prevalence/overview studies were published that focused on the incidence of lower back pain in hospital nurses in direct care).

The first study, published by Mekonnen (2019) in Ethiopia, with the title "Work-Related Factors Associated with Lower Back Pain Among Nurse Professionals in East and West Wollega Zones, Western Ethiopia", included 418 respondents in total. Its aim was to research the relationship between lower back pain incidence and the work factors related to LBP incidence in nurses in public hospitals in Western Ethiopia. The target population were nurses with at least 12 months of professional experience in direct hospital care. Nurses on sick leave, maternity leave or other leave were eliminated from the study. The data were collected by means of interviews and the questions were structured according to the standardized Nordic musculoskeletal questionnaire and Von Korff's pain scale. The study found that lower back pain was experienced by 266 (63.6\%) nurses in public hospitals in Western Ethiopia in the preceding 12 months, and 142 (53.4\%) interviewed nurses mentioned lower back pain troubles during the preceding 7 days. Mekonnen (2019) concluded that the length of employment, the amount of working hours, and a lack of safety training have a considerable effect on the incidence of lower back pain in nurses. The findings support the significance of launching procedures aimed at prevention and monitoring of back injuries and pain. Limiting the excessive physical workload during shifts, as well as regular healthcare and safety manual handling training are necessary measures for reducing the incidence of lower back pain.

Another study published in the same year was the quantitative prevalence study by Fujii et al. (2019) with the title "Association between high fear-avoidance beliefs about physical activity and chronic disabling lower back pain in nurses in Japan". The study included nurses directly caring for patients from 12 different hospitals all over Japan. The questionnaire survey was designed to find out the social and demographic data from the respondents, together with issues related to lower back pain. The standardized questionnaires assessing the mental strain The Kessler Psychological Distress Scale (K-6) - and a questionnaire analyzing the issue of mental activity - Fear-Avoidance Beliefs Questionnaire (FABS) - were used to determine how physical activities performed by nurses and the influence of mental strain relate to the incidence of lower back pain. $75.9 \%$ of the interviewed nurses mentioned the occurrence of lower back pain during the preceding 12 months, and 58.7\% nurses experienced this kind of pain during the preceding four weeks. The results of this study revealed the relationship of the phys- ical workload and the incidence of chronic lower back pain in the interviewed nurses in Japan. Specifying the physical activities related to the incidence of lower back pain might be beneficial for the management of the issue of musculoskeletal lower back pain in nurses.

Three studies complying with the research criteria were published in 2018.

In his research, the first author (Suliman, 2018) focused on the "Prevalence of lower back pain and associated factors among nurses in Jordan". A total of 384 nurses (with at least 12 months of professional direct hospital care experience) filled in the non-standardized questionnaire assessing the prevalence of the lower back pain, describing the intensity of the pain on the numeric pain rating scale (0-10). 265 (69\%) of the nurses stated that they were experiencing back pain at that time, while 303 (78.9\%) had experienced the pain during the preceding 12 months, and 321 (83.6\%) nurses confirmed growing lower back pain.

A higher risk of lower back pain occurrence was found in nurses of a higher age, females, overweight, and length of professional experience. The necessity of sick leave as a consequence of lower back pain was found in $40 \%$ of the interviewed hospital nurses, while productivity was lower in $58.7 \%$, and $9 \%$ of nurses stated that they had been made to change ward. These findings point to the fact that lower back pain prevalence is a serious work-related issue among Jordan nurses, and that interdisciplinary measures need to be taken in order to reduce the lower back pain incidence rate.

A study with the lowest number of respondents $(n=80)$ was published by Nourollahi et al. (2018) under the title "Awkward trunk postures and their relationship with lower back pain in hospital nurses". Nurses working at eight different hospital wards in Iran were asked to take part in the research. The data was collected by means of interview, using questions from the standardized Nordic musculoskeletal questionnaire. The incidence of lower back pain was found in $72 \%$ Iranian nurses working in direct patient care in hospitals. The results of this study confirmed that awkward trunk postures during manual handling, together with excessive manual handling of immobile patients and repetitive monotonous spine movements increase the risk of lower back pain occurrence in professional nurses. In addition, the findings emphasize the necessity of launching procedures to reduce the incidence rate of back pain in nurses, in particular by introducing labour regulations based on ergonomic manual handling principles.

The last study of 2018, "Musculoskeletal Disorders: Prevalence and Associated Factors among District Hospital Nurses in Haiphong, Vietnam", was published by Luan et al. (2018). The research was conducted in 15 hospitals in the municipality of Haiphong, Vietnam, in 2017. The study included 1,179 nurses with at least 12 months of professional experience in direct hospital care for patients. Nurses with less than 12 months of professional clinical experience and nurses on sick leave or maternity leave were eliminated from the study. The study aimed to assess additional factors in the incidence of musculoskeletal disorders in nurses. The prevalence of musculoskeletal disorders was ascertained by means of an interview according to the standardized Nordic musculoskeletal questionnaire. The prevalence of musculoskeletal disorders was found in $74.7 \%$ of the researched population of nurses over the preceding 12 months, and in $41.1 \%$ over the preceding 7 days. The musculoskeletal pain occurred most frequently in the lower back (44.4\%) and in the neck (44.1\%). Due to the considerably higher incidence rate of the musculoskeletal disorders in nurses working in Haiphong hospitals, the authors recommended 
launching preventive measures to improve the working conditions and increase awareness of prevention of musculoskeletal disorders in nurses.

In 2017, Sanjoy et al. (2017) published their prevalence summary study under the title "Occupational factors and lower back pain: a cross-sectional study of Bangladeshi female nurses". The study was conducted in order to examine the influence of nurses' working conditions on the occurrence of lower back pain in Bangladeshi nurses. The study only included female nurses working in two major hospitals in Bangladesh ( $n=$ 229). The research data were collected by means of an interview based on the standardized Nordic musculoskeletal questionnaire and the Karasek's Job Content Questionnaire. The nurses in the researched group were 22 to 56 years old (average age was 55.54 years). The prevalence of lower back pain in the Bangladesh hospital nurses was $73 \%$ during the preceding 12 months. Nurses working in a state hospital mentioned a higher incidence rate of lower back pain than nurses working in the private sector. The prevalence of lower back pain was also confirmed to be significantly higher in older nurses and those with a higher BMI. The average age of the first lower back pain occurrence was calculated to be 31.55 years. The results of the study refer to the risk factors of the occurrence of lower back pain, namely due to insufficient support for employees, working overtime, and manual handling and lifting of patients using no lifting aids. The authors recommend that employers at medical institutions focus on increasing the support for their employees, in particular by reducing the time worked per week and limiting the frequency of manual lifting of patients, and improving other management of workplace condition.

Another study included in our research of the available literature was entitled: "Increased lower back pain risk in nurses with high workload for patient care: A questionnaire survey" (Shieh et al., 2016). Its authors intended to assess the increased risk of the occurrence of lower back pain in nurses with a high workload of patient care at a Medical Centre in Taiwan. The cross-sectional study included 788 nurses working in direct patient care, aged $20-29$ years $(83.4 \%)$ and $30-55$ years (16.5\%). The data was collected through an online non-standardized questionnaire. Incidence of lower back pain was found in $72 \%$ ( $n=567)$ of respondents over the preceding 12 months. The study confirmed the statistically significant correlation between the risk of the occurrence of lower back pain and the long-term intensive physical load for the spine due to manual handling. The average length of the respondents' shifts exceeded 9 hours. The authors of this research calculated that the risk of lower back pain in nurses increases by 35\% per each hour of the 9-hour working shift. Prolonged working shifts are connected with an increased LBP risk according to this study. The results indicate that the prolonged working hours, frequent overtime and caring for a high number of immobile patients contribute to the occurrence of lower back pain. The management of healthcare organizations should therefore minimalize these contributing factors to reduce nursing staff shortages. Furthermore, employers should also provide training and support in establishing ergonomic procedures for patient handling and manual handling - in order to support the prevention of lower back pain.

In the last analyzed study, entitled: "Hospital nurses' tasks and work-related musculoskeletal disorders symptoms: A detailed analysis", the authors (Serranheira et al. (2015) analyzed the impact of the typical "nurses" tasks in relation to the occurrence of lumbar, dorsal, wrist/hand and ankles/feet musculoskeletal symptoms. Nurses working in hospitals in Portugal were asked by the local nurses' association to take part in the online study from June 2010 to February 2011. The total of 1,396 participating nurses represented $5.2 \%$ of all nurses working in hospitals in Portugal $(n=26.920)$. The authors used the standardized Nordic musculoskeletal questionnaire, and the study results revealed the prevalence of lower back pain in $60.9 \%$ nurses over the preceding 12 months and $48.8 \%$ over the preceding 7 days. Since the prevalence of lower back pain was a significantly predominant musculoskeletal problem in the researched sample, the authors decided to conduct a more in-depth analysis of the typical tasks of nurses and their influence on the probability of the occurrence of an increased intensity of the lower back pain. The results of the test showed that when the nursing task of "feeding patients" was performed no more than once a day compared to ten times a day, it reduces the probability of lower back pain in $82 \%$ of people, and reduces the probability of high intensity lumbar back pain in $92.9 \%$ of people. The tasks related to the patient's hygiene and activities that required changes of position for a patient's comfort in bed. When performed two to five times a day, compared to a frequency of more than ten times, it reduced the probability of the occurrence of intense lower back pain by $71.6 \%$. The authors have concluded that nursing tasks performed more than ten times per shift, such as invasive intervention, assistance in hygiene and providing comfort for the patient in bed, mobilization of the patient and feeding, are very important occupational hazard which largely contribute to the occurrence of lower back pain in this profession.

\section{Conclusions}

The high incidence of musculoskeletal lower back pain is extensively discussed in professional sources. Nevertheless, insufficient attention is paid to the assessment of the safety of working conditions, the establishment of preventive safety procedures, and the evaluation of nurses in medical institutions. In this literary research, we have confirmed that despite the possibilities of using 21st century technologies the incidence of lower back disorders among the nurse population is still a very serious problem that affects $61 \%$ to $79 \%$ of researched nurses. Due to the fact that the medical industry requires employees to perform manual handling that could be done by lifting equipment, the nursing profession continues to be the most dangerous profession in relation to lower back disorders and injuries. The available professional sources also show that effective occupational safety and health measures are not sufficiently standardized or broadly implemented in the healthcare system worldwide.

The following working conditions have been identified as the most significant causes of the high incidence of musculoskeletal lower back pain among nurses in direct patient care: duration of professional clinical experience, working in shifts for longer than nine hours, overtime work, unsuitable working environment, excessive manual handling of immobile patients, and loading of the spine by monotonous movements and/or awkward trunk postures during the performance of nursing activities.

Among other significant factors, there is also a lack of awareness of the lower back pain risks.

No studies analyzing the prevalence of musculoskeletal lower back pain and its prevention among nurses in the $\mathrm{Czech}$ Republic have been found.

Based on the above findings, an analysis will be performed to study the intercultural differences in the prevalence of lower back pain among nurses in the Czech Republic and Great 
Britain. The study should provide information on the current state of musculoskeletal health among nurses in both countries. It will contribute to the analysis and increase awareness of preventive regulations related to the safe manual handling of patients and their impact on the incidence of musculoskeletal disorders among nurses. By assessing the intercultural differences in the incidence of lower back pain, the analysis will emphasize the risks of occurrence of back disorders and will thus contribute to the prevention and protection of health in the nurse population.

Great Britain has been selected for the intercultural comparison with the Czech Republic due to the fact that it has implemented long-term national preventive strategies and measures against the occurrence of musculoskeletal pain in healthcare professionals.

Previous studies have confirmed that chronic musculoskeletal system disorder is related to the frequency of taking sick leave, as well as to changes of profession and premature ter- minations of employment in healthcare institutions - which in some regions may worsen the nursing shortage. Reducing the high proportion of musculoskeletal disorders and securing better working conditions for nurses should therefore be a priority for healthcare organisations worldwide.

\section{Ethical aspects and conflict of interests}

The literary research has been carried out in compliance with ethical rules. Our literary research and the methods used have not been subject to written consents of any particular persons. The authors declare that they have no conflict of interests.

\section{Acknowledgements}

The article was created with the support of the grant funded project: Intercultural Differences in Lower Back Pain Incidence among Nurses in the Czech Republic and Great Britain SGS09/LF/2019-2020 launched by the Faculty of Medicine of Ostrava University in Ostrava.

\section{Prevalence muskuloskeletální bolesti dolní části zad u všeobecných sester}

\section{Souhrn}

Cíl: Cílem rešerše je zhodnotit dostupné odborné poznatky o prevalenci muskuloskeletální bolesti dolní části zad u všeobecných sester $\mathrm{v}$ přímé péči v nemocnicích. Literární rešerše je východiskem pro výzkum, který analyzuje mezikulturní rozdíly v prevalenci bolesti dolní části zad u všeobecných sester v České republice a Velké Británii.

Metodika: Literární rešerše - klíčová slova dle PICO a s využitím booleovských operátorů vyhledávaná ve vědeckých elektronických databázích (MEDLINE, SCOPUS, EMBASE, CINAHL).

Výsledky: Vyhledáno bylo celkem 370 odborných zdrojů. Kritické analýze bylo podrobeno 15 zdrojů splňujících stanovená kritéria a k finální analýze bylo zvoleno celkem 8 studií, které byly zaměřeny na prevalenci muskuloskeletální bolesti dolní části zad u všeobecných sester $\mathrm{v}$ přímé péči $\mathrm{v}$ nemocnicích.

Závěr: V rámci provedené literární rešerše jsme ověřili, že problematika výskytu bederních bolestí u populace všeobecných sester je i přes moderní technologii 21. století stále velmi závažným problémem postihujícím v rozmezí 61 až 79 \% zkoumaných sester. Z dostupných odborných zdrojů také vyplývá, že implementace efektivních preventivních opatření bezpečnosti práce není ve světě dostatečně standardizována a ve zdravotnictví široce implementována. Výsledky literární rešerše prokázaly, že pracovní podmínky práce sestry v přímé péči, nedostatečné povědomí o pracovních rizicích, malý důraz na prevenci a edukaci sester v bezpečné manipulaci s pacienty mají vliv na výskyt muskuloskeletální bolesti dolní části zad. Dlouhodobá problematika bolesti dolní části zad může mít podíl na pracovní neschopnosti, změně profese a předčasném odchodu do důchodu, což může v některých regionech ještě více prohlubovat problém nedostatku sester.

Klíčová slova: muskuloskeletální bolesti dolní části zad; prevalence; prevence; rizikové faktory; všeobecná sestra

\section{References}

1. Abolfotouh SM, Mahmoud K, Faraj K, Moammer G, ElSayed A, Abolfotouh MA (2015). Prevalence, Consequences and Predictors of Low Back Pain among Nurses in a Tertiary Care Setting. In Orthop 39(12): 2439-2449. DOI: 10.1007/s00264015-2900-x.

2. Andersen LL, Vinstrup J, Villadsen E, Jay K, Jakobsen MD (2019). Physical and Psychosocial Work Environmental Risk Factors for Back Injury among Healthcare Workers: Prospective Cohort Study. Int J Environl Res Public Health 16(22): 4527. DOI: 10.3390/ijerph16224528.

3. Commission European (2015). EU Strategic Framework on Health and Safety at Work 2014-2020. EU - North Africa Seminar: Strategies for Better Occupational Safety and Health, no. April: 28. [online] [cit. 2020-01-03]. Available from: https://eur-lex.europa.eu/legal-content/EN/TXT/ PDF/?uri=CELEX:52014DC0332

4. D'Agostin F, Negro C (2017). Symptoms and Musculoskeletal Diseases in Hospital Nurses and in a Group of University Employees: A Cross-Sectional Study. Int J Occup Saf Ergon 23(2): 274-284. DOI: 10.1080/10803548.2016.1198092.
5. Dlungwanen T, Voce A, Knight S (2018). Prevalence and Factors Associated with Low Back Pain among Nurses at a Regional Hospital in Kwazulu-Natal, South Africa. Health SA Gesondheid 23: 1082. DOI: 10.4102/hsag.v23i0.1082.

6. EU-OSHA - European Agency for Safety and Health at Work (2015). Work-related diseases. [online] [cit. 2020-02-03]. Available from: https://osha.europa.eu/en/themes/workrelated-diseases

7. Fiter J, Werdhani RA, Wahyuni S (2018). Effect of Back-Exercise on the Level of Pain and Disability among Hospital Ward Nurses with Subacute and Chronic Nonspecific Low Back Pain. Journal of Physics: Conference Series 1073(6): 1-8. DOI: 10.1088/17426596/1073/6/062027

8. Fujii T, Oka H, Takano K, Asada F, Nomura T, Kawamata K, et al. (2019). Association between High Fear-Avoidance Beliefs about Physical Activity and Chronic Disabling Low Back Pain in Nurses in Japan. BMC Musculoskeletal Disorders 20(1): 1-10. DOI: 10.1186/s12891-019-2965-6.

9. Gaowgzeh RAM (2019). Low Back Pain among Nursing Professionals in Jeddah, Saudi Arabia: Prevalence and Risk Factors. J Back Musculoskelet Rehabil 32(4): 555-560. DOI: 10.3233/BMR-181218.

10. Genç A, Kahraman T, Göz E (2016). The Prevalence Differences of Musculoskeletal Problems and Related Physical Workload 
among Hospital Staff. J Back Musculoskelet Rehabil 29(3): 541-547. DOI: 10.3233/BMR-160655.

11. Hartvigsen J, Lauritzen S, Lings S, Lauritzen T (2005). Intensive Education Combined with Low Tech Ergonomic Intervention Does Not Prevent Low Back Pain in Nurses. Occup Environ Med 62(1): 13-17. DOI: 10.1136/oem.2003.010843.

12. Haslam C, Clemes S, McDermott H, Shaw K, Williams C, Haslam R (2007). Manual Handling Training Investigation of Current Practices and Development of Guidelines Prepared by the Work and Health Research Centre Investigation of Current Practices and Development of Guidelines. [online] [cit. 2020-0203]. Available from: http://dspace.lboro.ac.uk/2134/8353

13. Institute of Health Information and Statistics of the Czech Republic (2013). Ukončené případy pracovní neschopnosti pro nemoc a úraz 2012. Prague. [online] [cit. 2020-02-03]. Available from: https://uzis.cz/sites/default/files/knihovna/uppn2012. pdf

14. Karahan A, Bayraktar N (2013). Effectiveness of an Education Program to Prevent Nurses' Low Back Pain. Workplace Health Saf 61(2): 73-78. DOI: 10.1177/216507991306100205.

15. Kneafsey R, Clifford C, Greenfield S (2015). Perceptions of Hospital Manual Handling Policy and Impact on Nursing Team Involvement in Promoting Patients' Mobility. J Clin Nurs 24(1-2): 289-299. DOI: 10.1111/jocn.12659.

16. Laštovková $\mathrm{A}$, Nakládalová $\mathrm{M}$, Fenclová Z, Urban $\mathrm{P}$, Gad'ourek P, Lebeda T, et al. (2015). Low-Back Pain Disorders as Occupational Diseases in the Czech Republic and 22 European Countries: Comparison of National Systems, Related Diagnoses and Evaluation Criteria. Cent Eur J Public Health 23(3): 244-251. DOI: 10.21101/cejph.a4185.

17. Lee SJ, Lee JH, Gershon RRM (2015). Musculoskeletal Symptoms in Nurses in the Early Implementation Phase of California's Safe Patient Handling Legislation. Res Nurs Health 38(3): 183-193. DOI: 10.1002/nur.21657.

18. Luan HD, Hai NT, Xanh PT, Giang HT, Van Thuc P, Hong NM, Khue PM (2018). Musculoskeletal Disorders: Prevalence and Associated Factors among District Hospital Nurses in Haiphong, Vietnam. Biomed Res Int 2018: 1-9. DOI: $10.1155 / 2018 / 3162564$.

19. Mekonnen TH (2019). Work-Related Factors Associated with Low Back Pain Among Nurse Professionals in East and West Wollega Zones, Western Ethiopia, 2017: A Cross-Sectional Study. Pain Ther 8(2): 239-247. DOI: 10.1007/s40122-0190129-x.

20. Mirmohammadi S, Yazdani J, Etemadinejad S, Asgarinejad H (2015). A Cross-Sectional Study on Work-Related Musculoskeletal Disorders and Associated Risk Factors Among
Hospital Health Cares. Procedia Manufacturing 3: 4528-4534. DOI: 10.1016/j.promfg.2015.07.468.

21. Nelson AL, Owen BD, Lentz KP, et al. (2003). Safe Patient Handling and Movement: A Guide for Nurses and Other Health Care Professionals. [online] [cit. 2020-01-03]. Available from: https://pdfs.semanticscholar.org/4d24/ ba20a17224b5ca82d2a0d167aadae01860e0.pdf

22. Nourollahi M, Afshari D, Dianat I (2018). Awkward Trunk Postures and Their Relationship with Low Back Pain in Hospital Nurses. Work 59(3): 317-323. DOI: 10.3233/WOR-182683.

23. Occupational Safety Research Institute Czech Republic (2016) Manipulace s pacienty ve zdravotnictví. [online] [cit. 202002-03]. Available from: https://zsbozp.vubp.cz/pracovnisprostredi/odvetvi/zdravotnictvi/284-manipulace-s-pacientyve-zdravotnictvi

24. Samaei SE, Mostafaee M, Jafarpoor H, Hosseinabadi MB (2017). Effects of Patient-Handling and Individual Factors on the Prevalence of Low Back Pain among Nursing Personnel. Work 56(4): 551-561. DOI: 10.3233/WOR-172526.

25. Sanjoy SS, Ahsan GU, Nabi H, Joy ZF, Hossain A (2017). Occupational Factors and Low Back Pain: A Cross-Sectional Study of Bangladeshi Female Nurses. BMC Res Notes 10(1): 173. DOI: 10.1186/s13104-017-2492-1.

26. Serranheira F, Sousa-Uva M, Sousa-Uva A (2015). Hospital Nurses Tasks and Work-Related Musculoskeletal Disorders Symptoms: A Detailed Analysis. Work 51(3): 401-409. DOI: 10.3233/WOR-141939.

27. Shieh SH, Sung FC, Su CH, Tsai Y, Hsieh VC (2016). Increased Low Back Pain Risk in Nurses with High Workload for Patient Care: A Questionnaire Survey. Taiwan J Obstet Gynecol 55(4): 525-529. DOI: 10.1016/j.tjog.2016.06.013.

28. Simon M, Tackenberg P, Nienhaus A, Estryn-Behar M, Conway PM, Hasselhorn HM (2008). Back or Neck-Pain-Related Disability of Nursing Staff in Hospitals, Nursing Homes and Home Care in Seven Countries-Results from the European NEXT-Study. Int J Nurs Stud 45(1): 24-34. DOI: 10.1016/j. ijnurstu.2006.11.003.

29. Skela-Savič B, Pesjak K, Hvalič-Touzery S (2017). Low Back Pain among Nurses in Slovenian Hospitals: Cross-Sectional Study. Int Nurs Rev 64(4): 544-551. DOI: 10.1111/inr.12376.

30. Suliman M (2018). Prevalence of Low Back Pain and Associated Factors among Nurses in Jordan. Nurs Forum 53(4): 425-431. DOI: $10.1111 /$ nuf.12269.

31. Warren G (2016). Moving and handling: reducing risk through assessment. Nurs Stand 30(40): 49-58. DOI: 10.7748/ ns.30.40.49.s45. 